\title{
„Kakucs-Turján mögött” bronzkori lelőhelyen végzett régészeti talaj-mikromorfológiai és talajtani vizsgálatok eredményei
}

\author{
${ }^{1}$ KovÁcs Gabriella, ${ }^{2}$ Kulcsár Gabriella, ${ }^{2}$ SeRlegi Gábor, ${ }^{3}$ Mateusz JAEGER, ${ }^{4}$ Nicole \\ TAYLOR és ${ }^{5}$ PETÖ Ákos \\ 1 'Matrica' Múzeum és Régészeti Park, Százhalombatta \\ ${ }^{2}$ MTA Bölcsészettudományi Kutatóközpont, Régészeti Intézet, Budapest \\ ${ }^{3}$ Adam Mickiewicz University, Institute of European Culture, Poznań \\ ${ }^{4}$ Christian-Albrechts-Universität zu Kiel Institut für Ur- und Frühgeschichte, Kiel \\ ${ }^{5}$ SZIE Természetvédelmi és Tájgazdálkodási Intézet
}

\section{Bevezetés}

A talajtani vizsgálatok (talajfúrás és talaj-mikromorfológia) segítségével számos olyan, a hagyományos régészeti technikákkal fel nem tárható információt gyüjthetünk, melyek hozzájárulnak az adott lelőhely részletesebb megismeréséhez. A talajfúrások lehetővé teszik nagyobb felületek, a lelőhely és annak szükebb vagy éppen tágabb környezetének viszonylag gyors és hatékony vizsgálatát (VARGA 2000; SÁNDOR 2011; PETŐ et al. 2013; SALÁtA et al. 2014). A talajmikromorfológiai vizsgálatok esetében is lehetséges kiterjedt mintavételezés (pl. Százhalombatta-Földvár, KovÁcs 2009; 2011), ugyanakkor azok jelentős idő- és költségigénye miatt gyakrabban használatosak mikro-léptékben megfogalmazott kérdések tisztázására; azaz adott lelőhelyen belül egy-egy részletkérdés (pl. aktivitási körzetek meghatározása, épületmegújítások stb.) megválaszolására. Mindkét módszer egyaránt alkalmas és egyre szélesebb körben használt a horizontális és vertikális változások nyomon követésére, az emberi tevékenység hatásának vizsgálatára (pl. DEZSÖ et al. 2009; BARCZI 2016).

A talaj-mikromorfológiai vizsgálatok során úgynevezett mamut vékonycsiszolatok készülnek (kb. 7x14 cm-es üveg lemezek), melyek a mikrokontextus vizsgálatát teszik lehetővé. Ezeket kiegészítve a nagyobb léptékü talaj fúrások eredményeivel, átfogó és egyben részletekben gazdag képet kaphatunk az adott lelőhelyről.

A Vatya-kultúra számos települése ismert a Kelet-Dunántúlon, a Duna mentén, a Duna-Tisza-közén és a Közép-Tisza-vidéken egyaránt (lásd többek között VICZE et al. 2005; REMÉNYI 2012; SZEVERÉNYI \& KULCSÁR 2012). Jelen tanulmány keretein belül a kultúra egyik nyíltszíni telepét, Kakucs-Turján mögött lelöhelyet vizsgáljuk a korábban említett két talajtani módszer segítségével.

A Kakucs-Újhartyán-Dabas háromszög által határolt területen, a Magyar Tudományos Akadémia Bölcsészettudományi Kutatóközpont Régészeti Intézete egy magyar-lengyel-német régészettudományi kutatási program keretében 2013 óta végez feltárásokat (KULCSÁR et al. 2014). A projekt központi eleme a „KakucsTurján mögött” megnevezésü lelőhely régészeti feltárása.

Postai cím: Kovács Gabriella, 'Matrica' Múzeum és Régészeti Park, 2440 Százhalombatta, Gesztenyés út 1-3.

E-mail: antropologus@yahoo.com 
Az árkokkal tagolt és körbevett bronzkori településen régészeti-talajtani (talajfúrásos) vizsgálatokat végeztünk azzal a céllal, hogy a lelőhely rétegrendjét tisztázhassuk (PETŐ et al. 2015 és 2016). A minimális bolygatást jelentő lényegében ún. non-invazív - fúrással feltárt szelvények vizsgálatával meghatároztuk és jellemeztük a terület felszínfejlődési és talajképződési viszonyait. Korábban részletesen tárgyaltuk a lelöhely talaj- és rétegviszonyait, valamint a lelőhely központi térrészén elhelyezkedö épületobjektumokon végzett régészeti talajtani vizsgálatok eredményeit (PETŐ et al. 2015). Ezen túlmenően külön dolgozatban tértünk ki a lelőhely árkainak és víznyerő objektumainak régészetitalajtani vizsgálati eredményeire is (PETÖ et al. 2016). A nagyfelbontású térképező fúrással végzett felmérés alapján sikerült megrajzolni egy homok textúrájú talajtani környezetben elhelyezkedő és ebben fejlődő, majd pusztuló lelőhely rétegtani viszonyait. Világossá vált továbbá, hogy a lelőhely egy egykori vízjárta, fluvioeolikus és alluviális üledékek mozaikjából kiemelkedő homokos lösz kiemelkedésen, háton helyezkedik el.

Jelen tanulmányban a lelőhelyen nyitott ásatási szelvényben végzett régészeti talaj-mikromorfológiai vizsgálat eredményeire támaszkodunk, ugyanakkor a korábbi fúrások, valamint a mikromorfológiai vizsgálat egymással összefüggésben álló, és egymást kiegészítő eredményeit is bemutatjuk. Célunk, hogy a régészeti talaj-mikromorfológia nyújtotta lelőhely-fejlődési ismereteket bemutassuk, valamint rávilágítsunk a két talajtani módszer kiegészítő jellegű természetére.

Jelen tanulmány a korábban közölt eredmények (PETÖ et al. 2015 és 2016) szerves folytatása és módszertanilag átfedésben vannak egymással.

\section{Anyag és módszer}

\section{A vizsgálati terület rövid tájföldrajzi jellemzése}

„Kakucs-Turján mögött” lelőhely Kakucs településtől délnyugatra a Dunavölgyi-főcsatorna mellett Kakucs, Dabas, Inárcs és Újhartyán települések határában helyezkedik el. Földrajzi értelemben a lelőhely a Kiskunsági-homokhát határán, a Pesti hordalékkúp-síkság, illetve a Pilis-Alpári-homokhát, illetve a Csepeli sík kistájak találkozási pontjában található. A lelőhely földrajzi környezetének táji jellemzői az említett három kistáj vonatkozó adataiból olvashatók ki. A lelöhely közvetlen környezetének domborzati viszonyaira jellemző, hogy az enyhén hullámos síkság orográfiai domborzattípusba sorolható, amelyet főként szélfútta (eolikus és fluvioeolikus) homoktakaró fed (MAROSI \& SOMOGYI 1990; DÖVÉNYI 2010). A monotonnak tekinthető geomorfológiai és geológiai környezetet löszderivátumok megjelenése, valamint iszapos és homokos fluviális üledékekkel feltöltődött ártéri síkok teszik változatosabbá. A mérsékelten meleg-meleg éghajlatú földrajzi tájra alapvetően vízhiány jellemző, ugyanakkor a területtől északra elhelyezkedő Turjánvidék változatos vizes élőhelyeknek is otthont ad. A földtani jellegzetességekkel összhangban a domináns talajtípus a futóhomok, a kötöttebb humuszos homok, valamint homokon fejlődött csernozjom talajok. 
A régészeti talaj-mikromorfológia módszertana

A talaj-mikromorfológiai mintavételezésre 2015 augusztusában került sor. A mintavételezés során az elsődleges cél az ásatási szelvényben található objektumok, egykori felszínek mintázása volt, az emberi tevékenység és annak környezet átalakító szerepének megfigyelése céljából (1. ábra). A vizsgálat nem csupán a lelöhely részletesebb megismeréséhez járul hozzá, hanem összehasonlító anyagot is biztosít a Vatya kultúra Százhalombatta-Földvár nevü tell telepének anyagához. Ily módon a későbbiekben lehetővé válik a kultúra különféle településeinek (egy- és többrétegü telepek) talaj-mikromorfológiai összehasonlítása.

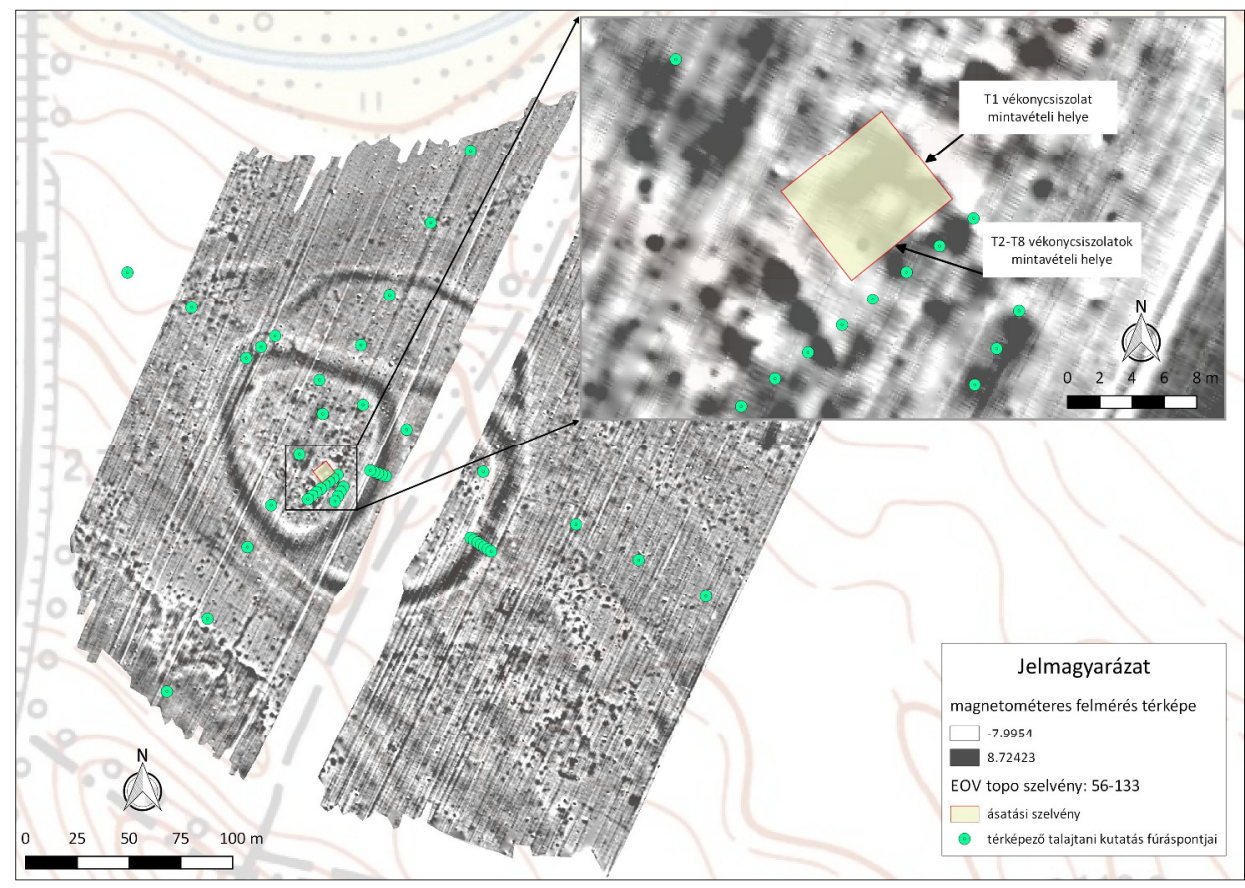

$$
\text { 1. ábra }
$$

Kakucs-Turján mögött lelőhely magnetométeres felmérésének eredménytérképe, a térképező talajtani kutatás fúráspontjai, a feltárási szelvény, valamint a mikromorfológiai mintavételezés helye.

Jelen kutatás keretein belül 8 darab minta került elemzésre (2. ábra), melyek T1-T8 jelöléssel lettek ellátva. A mintavétel úgynevezett Kubiëna-dobozok segítségével történt. Ezek a fémdobozok biztosítják a minták bolygatatlanságát a szállítás és az azt követő feldolgozás során, ami a módszer tekintetében alapkövetelmény. A kinyert minták szárítást követően, mügyantás konszolidálás, szeletelés és polírozás során érik el megfelelő vastagságukat (ca. $30 \mu \mathrm{m})$ (MURPHY 1986). Ez a vastagság biztosítja, hogy a talajanyagból (antropogén üledékből) képzett szeletek a fény által átjárhatók, ami pedig a mikroszkópi megfigyelések alapja. 
A vékonycsiszolatok vizsgálata Nikon Eclipse E200-as polarizációs mikroszkóppal történt, 20x, 40x, 100x és 200x-os nagyításokat használva. A mikrofotók egy nikollal $(1 \mathrm{~N})$ és keresztezett nikollal $(+\mathrm{N})$ is készültek az összetevők (szerves és szervetlen anyagok) meghatározása és bemutatása céljából. A mikrofotókon látható skála mértéke: $1000 \mu \mathrm{m}(1 \mathrm{~mm})$. A finom és durva összetevők arányának megállapításakor az $500 \mu \mathrm{m}$ alatti összetevők kerültek a finom, míg az e felettiek a durva mérettartományba. Az összetevők arányát vizuális becsléssel határoztuk meg (STOOPS 2003).

A megfigyelt összetevők táblázatos formában kerültek megjelenítésre a könnyü összehasonlíthatóság okán. A rétegek leírásakor a Százhalombatta-Földvár lelőhely esetében kidolgozott (KOVÁCS 2009) mikromorfológiai megfigyelési táblázat került alkalmazásra a későbbi összehasonlíthatóság érdekében. A rétegek struktúráját a durva/finom összetevők arányával, a réteg tömörödöttségével (porozitás), és a bioturbáció (talajlakó élőlények keverő hatása) mértékének erősségével jellemeztük. A szervetlen (ásványi) összetevők esetében a leggyakrabban előforduló ásványok kerültek rögzítésre. A biológiai eredetü szervetlen maradványok között a fitolit, az égett fitolit, illetve ezek esetleges szferolitokkal való együttes megjelenése (trágya, égett trágya), a kovamoszat vázak (pl. többek között tengeri üledék jellemző komponensei) és a mészváz került megfigyelésre. A szerves összetevők esetében a növényi eredetű komponensek (faszén, gomba szklerócium (többnyire modern bolygatás jelzői) és a lebomlott növényi anyagok) kerültek megfigyelésre. Itt megjegyzendő, hogy amennyiben adott lelőhely esetében a nem szenült és nem teljes mértékben lebomlott növényi anyag megőrzése szempontjából kedvező feltételek alakultak ki, ott ezek megfigyelhetők és az összes növényi szerves anyag mennyiségének a részét képezik. Az antropogén eredetü összetevők között egyaránt megtalálhatók szerves és szervetlen, növényi és állati eredetű anyagok. Ezek külön kategóriaként kerültek leírásra, hisz ezek bizonyos tevékenységhez vagy adott terület használatához köthető mikro fragmentumok (pl. COURTY et. al 1994; MATTHEWS et. al 1994) (vö. 1-8 táblázat kategóriái).
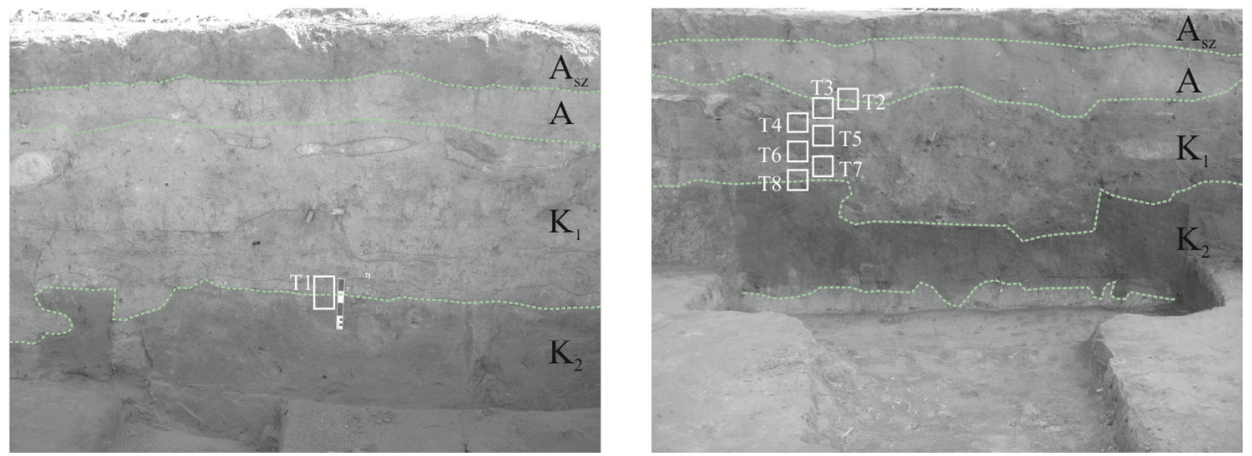

2. ábra

A talaj-mikromorfológiai minták elhelyezkedése Kakucs-Turján mögött lelőhely ásatási szelvényének falában. 


\section{A korábban végzett térképezö talajfúrás eredményeinek rövid összefoglalása}

A területen a sekélyföldtani fúrások eszközének segítségével alkalom nyílt arra, hogy feltérképezzük a bronzkori település talajtani, illetve sekélyföldtani viszonyait (PETŐ et al. 2015 és 2016). Ennek érdekében egy nagyfelbontású és célzott kutatófúrási protokollt valósítottunk meg, amely amellett, hogy alkalmas a terület részletes és pontos talajtani, üledéktani és rétegtani viszonyainak feltérképezésére, segítette a régészeti lelőhely fejlődéstörténetének, illetve tafonómiájának megértését is (1. ábra).

A nagyfelbontású térképező fúrással, helyszíni talajvizsgálati módszerekkel, valamint alapvető laboratóriumi mérések (TOC\%; $\mathrm{P}_{\text {összes }}, \mathrm{pH}\left(\mathrm{H}_{2} \mathrm{O}\right)$ és $\mathrm{pH}(\mathrm{KCl})$, só\%, $\mathrm{CaCO}_{3} \%, \mathrm{~K}_{\mathrm{A}}$ ) elvégzésével meghatároztuk és leírtuk a lelőhely recens talajtakaróját. A lelőhely megközelítőleg 100 méteres átmérőjét az észak-déli és a kelet-nyugati irányokban kialakított, egyenként 10-10 darab felvételi ponttal jellemzett fúrássorozat írja le.

Ezen túlmenően, a fedő talajképződmény alatt meghatároztuk az antropogén hatásra fejlődött és módosult talajok, valamint üledékek vertikális és horizontális kiterjedését. Ennek keretében vizsgáltuk a hármas tagolású lelöhely kerítőárkainak betöltését, illetve az épületobjektumok által megjelenített megtelepedési és pusztulási rétegeket (PETŐ et al. 2015 és 2016).

Az épületobjektumokat átvágó fúrássorozatok során meghatározott antropogén üledékrétegek (kultúrrétegek) az egykori megtelepedés, a helyben lakásból származó antropogén anyag-felhalmozódás, valamint a későbbi, a lelőhelyet lezáró pusztulási rétegek egymáshoz viszonyított helyzetére utalnak.

\section{Vizsgálati eredmények és megvitatásuk}

\section{A lelöhely eltemetett talajának vizsgálata}

A lelöhelyen belül végzett fúrások alapján (nem értjük ide az árkok és a ciszterna/kút típusú jelenségeket) az alábbi leegyszerüsített rétegtani beosztás a meghatározó a megtelepedéssel érintett lelöhelyrészeken: recens talaj $\rightarrow K_{1}$ (megtelepedési és pusztulási réteg) $\rightarrow \mathrm{K}_{2}$ (az eredeti megtelepedés bolygatott járószintje és az eltemetett humuszos feltalaj átkeveredésével létrejött kultúrréteg) $\rightarrow$ a területre jellemző alapkőzet (vö. PETŐ et al. 2015 2. és 4. ábra). A megfigyelések alapján valószínűsítjük, hogy a lelőhely megtelepedéskori járószintjét a több helyen is jól detektálható $\mathrm{K}_{1} / \mathrm{K}_{2}$ réteghatár jelöli ki. $\mathrm{Az}$ épületekkel tarkított térrészen a $\mathrm{K}_{2}$ kultúrréteg az eredeti járószinten megvalósuló talajbolygatás (keverő hatás, gödörmélyítés stb.) eredményeképpen eltérő mértékben tartalmaz antropogén szemcséket (PETÖ et al. 2015 2. ábra: KT-05-KT08 fúrások). A helyben lakásból származóan felhalmozódó debris anyag pedig a $\mathrm{K}_{1} / \mathrm{K}_{2}$ réteghatáron akkumulálódott. Ebben a vonatkozásban a $\mathrm{K}_{1}$ rétegre nemcsak a település felhagyása után megvalósuló pusztulási anyag-felhalmozódásként kell tekintenünk, hanem olyan antropogén üledékként definiálhatjuk, amely vegyesen foglalja magában a helyben lakásból származó és a későbbi pusztulásból származó 
omladék anyagot (is). Ezt - a morfológiai jegyeken és az egyes rétegek térbeli elhelyezkedésén alapuló - feltételezést alátámaszthatja a $\mathrm{K}_{1}$ és $\mathrm{K}_{2}$ mintáiban mért összes foszfortartalom, illetve szervesanyag-tartalom különbség (PETŐ et al. 2015: 1. táblázat). (A $\mathrm{K}_{2}$ réteget, annak antropogén behatása miatt következetesen rétegnek és nem eltemetett talajszintnek nevezzük, illetve ezt a terminológiát követjük, hiszen a fúráspontokon feltárt magminták helyszíni talajvizsgálati eredményei alapján az egykori humuszos feltalajt érhette olyan mértékü bolygatás, hogy az módosult talajképződményként inkább a "réteg" megnevezést igényli.)

A fúrások tehát kimutatták a lelőhely egykori eltemetett talajszintjét, amelyet csak kevés esetben tudtunk a fúrómagok helyszíni vizsgálata során érintetlennek, klasszikus $\mathrm{A}_{\mathrm{p}}$-szintnek leírni. Sokkal inkább az eredeti humuszos talajfelszínen megtelepedő, majd a helyben lakás eredményeképpen eltérő mértékben a természetes feltalajt átkeverő tevékenység miatt módosult talajként, kultúrrétegként írtuk le.

Ezt a $\mathrm{K}_{2}$ réteget a T1-es kódszámmal jelölt talaj-mikromorfológiai minta jellemzi.

A T1-es minta két részre osztható (3. ábra). A " $b$ " jelü rész az eltemetett talajt képviseli. Ez többnyire ásványi anyagokból áll. 50\%-ban tartalmaz kvarcot, melyet kőzetliszt finomságú anyag köt össze (homokos vályog talaj). A domináns kvarc mellett polikristályos kvarc, csillám (muszkovit), illetve kis számban klorit kristályok voltak megfigyelhetőek (1. táblázat).

\section{1. táblázat}

A T1 kódjelzésű talaj mikromorfológiai mintából készített vékonycsiszolatok vizsgálatának eredményei, valamint a mikro-rétegeket leíró megfigyelések összefoglalása.

\begin{tabular}{|c|c|c|c|}
\hline \multicolumn{4}{|c|}{$\mathrm{T} 1$} \\
\hline \multirow{3}{*}{ (1) Vizsgálati szempontok } & (2) Rétegbontás & $\mathrm{a}$ & $\mathrm{b}$ \\
\hline & (3) Réteg vastagsága & $\begin{array}{c}5,4-5,8 \\
\mathrm{~cm}\end{array}$ & $\begin{array}{c}3,8-4,0 \\
\mathrm{~cm}\end{array}$ \\
\hline & (4) Réteg alsó határa & (q) elmosódott & - \\
\hline \multirow{3}{*}{ (a) Struktúra } & $\begin{array}{l}\text { (f) Durva / finom összetevők aránya } \\
(500 \mu \mathrm{m})\end{array}$ & $5 / 95$ & $5 / 95$ \\
\hline & (g) Porozitás & $30-40 \%$ & $10 \%$ \\
\hline & (h) Bioturbáció & (r) erős & (s) enyhe \\
\hline \multirow{4}{*}{ (b) Ásványi összetevők } & (i) Kvarc & $40-50 \%$ & $50 \%$ \\
\hline & (j) Polikristályos kvarc & $2-5 \%$ & $2-5 \%$ \\
\hline & (k) Muszkovit & $<2 \%$ & $<2 \%$ \\
\hline & (1) Klorit & $<2 \%$ & $<2 \%$ \\
\hline $\begin{array}{l}\text { (c) Biológiai eredetü } \\
\text { szervetlen maradványok }\end{array}$ & (m) Mészváz (csiga, kagyló, fosszília) & $<2 \%$ & (t) né \\
\hline (d) Szerves összetevők & (n) Faszén & $<2 \%$ & $<2 \%$ \\
\hline \multirow{2}{*}{ (e) Antropogén összetevők } & (o) Csont & $<2 \%$ & né \\
\hline & (p) Kerámia töredék & $<2 \%$ & $n e ́$ \\
\hline
\end{tabular}

né: nem észlelt 
Az " $a$ " jelü réteg nagy részét égett és nem égett homokos vályog darabok teszik ki (3. ábra). A lelőhelyről származó minták megfigyelései alapján ezek alkotják az egyes falak és járószintek anyagát is, ugyanakkor mivel igen apró darabokról van szó, nem lehet őket egyértelmüen fal vagy járószint anyaghoz kötni, így a táblázatban nem is szerepelnek (1. táblázat). Régészeti értelemben padlónak nevezzük a falak által körbevett épület maradványokat, melyek anyagukat tekintve lehetnek úgynevezett föld vagy agyagpadlók. Ezek felületén találhatjuk meg a korabeli ember által hátrahagyott tárgyakat, melyeket a ház összeomlásakor keletkező omladék takar. Határozásukkor egyrészt támaszkodunk a régészek terepi megfigyeléseire, mikroszkópos határozásuk pedig referencia kollekciók segítségével történik (KovÁCS 2009). A padlók esetében egy vízszintes és horizontális irányban is futó repedéshálózat alapján feltételezhető az azt ért terhelés, vagyis járás, ami ilyen apró töredékek esetén sok esetben nem figyelhető meg. A patics falak esetében pedig a benne lévő szerves soványítás alapján határozható meg a fal anyag, vagyis a patics. A fal/járószint darabokat ért égés nem in situ, így ezek másodlagosan kerültek ide. Emberi tevékenységre utal a kisszámú és apró méretü csont-, kerámia- és faszéntöredék is, de ezek olyan kis számban és olyan apró méretben vannak jelen, hogy tevékenységhez nem köthetőek. Erős bioturbáció látható ebben a rétegben a talajlakó élőlények nagyfokú intenzitásának következtében. A lazább talajállapot (30-40\% porozitás) is ennek a következménye. A talajlakók aktivitásának köszönhetően a későbbiekben a talaj felszínére került fal/padló töredékekből, kisebb darabok az alsó (b) rétegbe keveredtek.

Ezt a mikromorfológiai megfigyelést jól kiegészítik a fúrásokban tapasztaltak, azaz, hogy szinte minden esetben került elő antropogén eredetủ szemcse, illetve bolygatás nyoma is a megtelepedési rétegből $\left(\mathrm{K}_{2}\right)$. Az eltemetett talajon egyértelmủen emberi tevékenység nyomai láthatók, vagyis a korabeli talaj felszínén (eltemetett A-szint) történt a megtelepedés. A mintavétel helyén nincs nyoma a korabeli felszín modifikációjának, bár az észlelt fal/járószint darabok emberi tevékenységhez köthetők, a csiszolat megfigyelései alapján nem valószínű, hogy itt in situ padlót látunk. Fontos kiemelni, hogy a kiterjedt kutatófúrásokkal sikerült árnyaltabb képet kapnunk erről a rétegről, és több helyen úgy tapasztaltuk, hogy akár 50-100 cm-es relatív mélység különbség is lehet az egymáshoz közel eső területeken a $\mathrm{K}_{2}$ vonatkozásában, ami egyértelmúen arra mutat, hogy a helyben lakás nem egyformán, és eltérő intenzitással bolygatta a megtelepedési szintként definiálható egykori humuszos feltalajt (vö. gödrök, oszlop és cölöplyukak, kerítő és vízelvezető árkok kialakítása). 
a

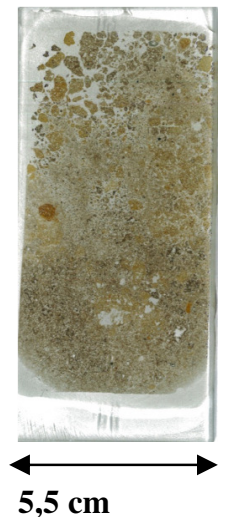

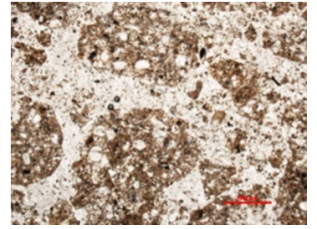

(a) Mátrix

(1N, 2X-es nagyítás*)

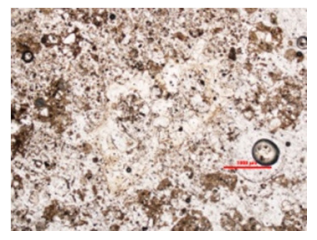

(b) Csont töredék

(1N, 2x nagyítás)

b

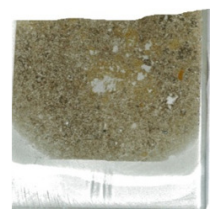

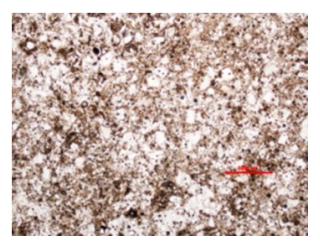

(a) Mátrix

(1N, 2X-es nagyítás)

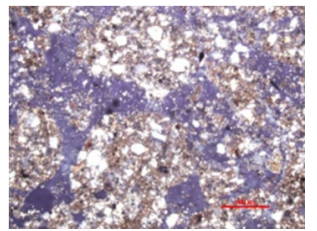

(a) Mátrix

(+N, 2X-es nagyítás)

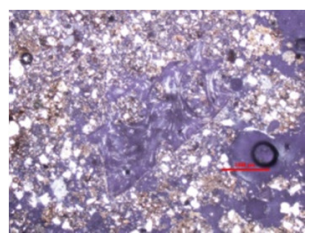

(b) Csont töredék (+N, 2x nagyítás)

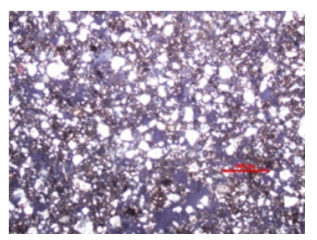

(a) Mátrix

(+N, 2X-es nagyítás)

\section{3. ábra}

A T1 kódjelzésü talaj mikromorfológiai mintából készített vékonycsiszolat és a benne található rétegekről készített mikrofotók.

Megjegyzés: A mikrofotók esetén a nagyítás az objektív nagyítására vonatkozik minden esetben, a tényleges nagyítás annak tízszerese.

A mikroszkópos megfigyelések, vagyis a töredékek kerekded formája, a réteg lazasága, bolygatottsága, a töredékek random orientációja áthalmozott anyagra utal. Bár a két réteg (az eltemetett talaj és a rajta lévő megtelepedési réteg) elválása egyértelmü, az eltemetett talajba keveredett antropogén eredetü mikrofragmentumok azt mutatják, hogy az eredeti talaj eltemetődése és rajta a feltöltődés fokozatos volt, hisz a talajlakók aktívan rész vettek a két közeg határának „összedolgozásában”.

Véleményünk szerint a T1-es mikromorfológiai minta egyértelmủen kimutatta, a fent említett $K_{1}$ és $K_{2}$ antropogén üledékösszletek határrétegét, és egzakt 
megfigyelésekkel árnyalta a két egymástól morfológiailag eltérő, de genetikájukat tekintve egymással kapcsolatban álló réteget.

\section{A megtelepedési réteg vizsgálata}

A T2-T8 jelzéssel ellátott mintasorozat a településen megfigyelt, egymáshoz képest vertikálisan elhelyezkedő két feltételezett padlót (T4 és T7) a köztük, illetve az alattuk és felettük található rétegeket mintázza. Az átfedéssel vett minták ily módon az időbeni változást mutatják (2. ábra).

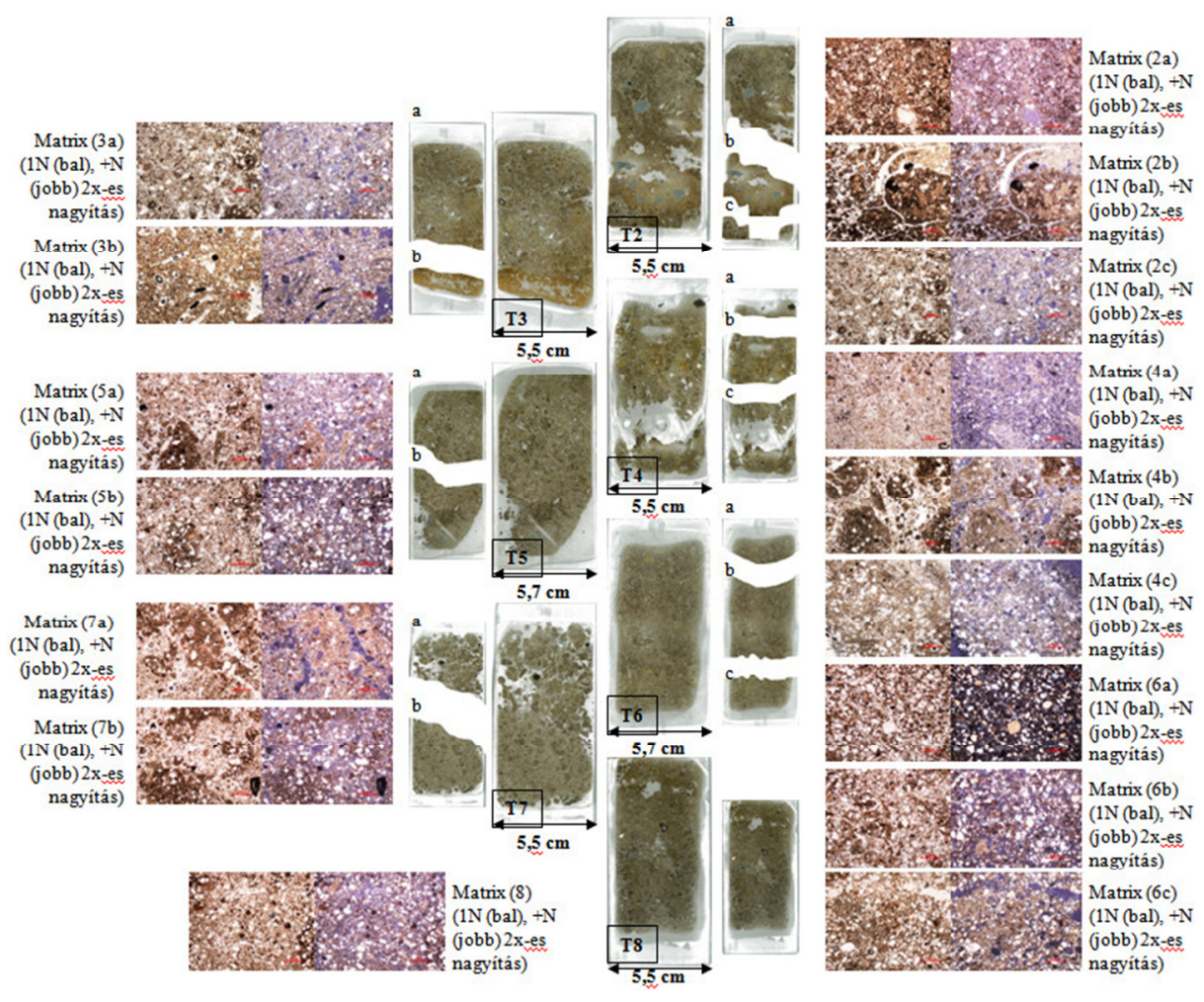

4. ábra

A T2-T8 kódjelzésủ talaj mikromorfológiai mintákból készített vékonycsiszolatok és az egyes rétegek mikroszkópi képe (a nagyítás mértéke az objektív nagyítására vonatkozik).

A fúrások talajvizsgálati eredményei kimutatták, hogy ez a réteg a lelőhely majdnem teljes területén előfordul, ugyanakkor eltérő vastagságban jelentkezik. A régészeti feltárást megelőző térképező kutató fúrások során a lelőhely központi térrészen elhelyezkedő épületobjektumok területén két fúrássorozat mentén végeztük el a fúrásokat (PETŐ et al. 2015: 1. és 4. ábra). Ennek fényében a fúrások során tapasztaltak validálása, az eredmények finomítása a T2-T8-as mintasorozattal 
megvalósítható. Ez a mintasorozat a kutató fúrások során meghatározott $\mathrm{K}_{1}$ munkakóddal ellátott megtelepedési és pusztulási réteg részletes kibontását adja meg.

Az épületobjektumokat fedő recens talaj (mely egy homokon fejlődött csernozjom talaj tulajdonságait mutatta) humuszos feltalajának (A-szint) mélysége és tulajdonságai egységesek; alatta közvetlenül a $\mathrm{K}_{1}$ kultúrréteg települ. A mátrixban szürkés sárgásbarna (10YR 4/2) színü, de tarka, foltos antropogén üledék kifejezetten nagy mennyiségben tartalmaz paticstörmeléket, kerámiamaradványokat, hamus mikro-rétegeket, valamint faszénszemcséket. Textúrában nem válik el élesen sem a felette települő humuszos feltalajtól, sem az alatta települö antropogén üledékrétegtől (PETÖ et al. 2015: 1. táblázat). Ezt a réteget a központi térrészen mélyített több fúrásponton is detektáltuk. A $\mathrm{K}_{1}$ kultúrréteg alatt egy színben jellemzően sötétebb, sötétbarna (10YR 3/3), homokos vályog fizikai féleségü réteg települ, amely fent tárgyalt $\mathrm{K}_{2}$ réteget jeleníti meg.

A mintákból készített vékonycsiszolatokat és a mikro rétegeket jellemző mikrofotókat a 4. ábra tartalmazza. A mintákhoz tartozó megfigyeléseket pedig a 2-8. táblázat foglalja össze.

A minták leírásának sorrendje a mélyebben elhelyezkedőtől (T8) a felszínhez közelebbi minták felé vezet (T2). Ily módon a folyamatok egymásra épülése és időbeli fejlődése is könnyen bemutathatóvá válik.

A T8-as mintában rétegződés nem figyelhető meg (2. táblázat). A minta felső részén hamu darabok láthatók, de ezek nem alkotnak összefüggő réteget. In situ égésre utaló nyom sincs, illetve a hamu töredékek is lekerekített formában vannak jelen, ami másodlagos lerakódásra, azaz áthalmozott anyagra utal (5. ábra).

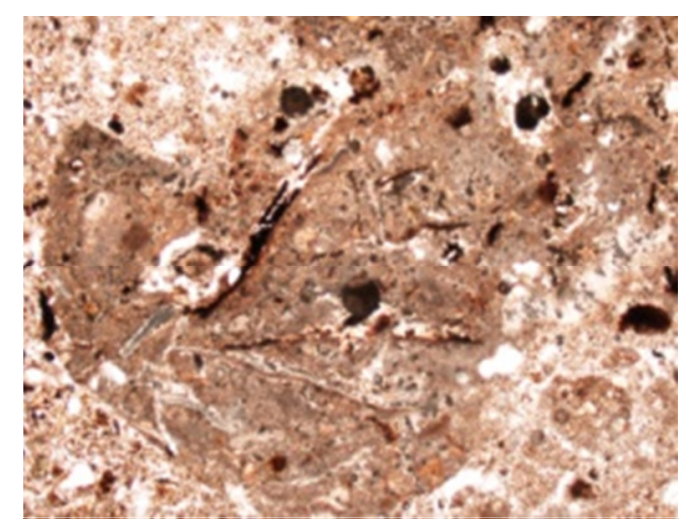

5. ábra

Hamu faszén darabokkal (1N, 2X-es nagyítás) a T8-as vékonycsiszolatban. 


\section{2. táblázat}

A T8 kódjelzésủ talaj mikromorfológiai mintákból készített vékonycsiszolatok vizsgálatának eredményei, valamint a mikro-rétegeket leíró megfigyelések összefoglalása.

\begin{tabular}{|c|c|c|}
\hline \multicolumn{3}{|c|}{ T8 } \\
\hline \multirow{3}{*}{ (1) Vizsgálati szempontok } & (2) Rétegbontás & $\mathrm{a}$ \\
\hline & (3) Réteg vastagsága & $9,6 \mathrm{~cm}$ \\
\hline & (4) Réteg alsó határa & - \\
\hline \multirow{3}{*}{ (a) Struktúra } & $\begin{array}{l}\text { (f) Durva / finom összetevők aránya } \\
(500 \mu \mathrm{m})\end{array}$ & $5 / 95$ \\
\hline & (g) Porozitás & $10-20 \%$ \\
\hline & (h) Bioturbáció & (r) enyhe \\
\hline \multirow{4}{*}{ (b) Ásványi összetevők } & (i) Kvarc & $30-50 \%$ \\
\hline & (j) Polikristályos kvarc & $2-5 \%$ \\
\hline & (k) Muszkovit & $<2 \%$ \\
\hline & (1) Klorit & $<2 \%$ \\
\hline $\begin{array}{l}\text { (c) Biológiai eredetü } \\
\text { szervetlen maradványok }\end{array}$ & (m) Mészváz (csiga, kagyló, fosszília) & $<2 \%$ \\
\hline (d) Szerves összetevők & (n) Faszén & $<2 \%$ \\
\hline \multirow{3}{*}{ (e) Antropogén összetevők } & (o) Hamu & $<2 \%$ \\
\hline & (p) Kerámia töredék & $<2 \%$ \\
\hline & (q) Padló töredék & $10-20 \%$ \\
\hline
\end{tabular}

né: nem észlelt

A mintában jelen vannak a mindennapi háztartási tevékenységek mikro töredékei: kerámia, hamu, faszén, de elenyésző számban. A minta alsó harmadában feltételezhetően padlóból származó töredékek vannak. Mivel a töredékek igen kis méretúek és a padlókra jellemző repedéshálózat csak kevésen figyelhető meg, itt az azonos anyagok elve alapján történt a feltételezés.

A T7-es minta két részre osztható (4. ábra; 3. táblázat). A felső ("a") réteg közel felét padló darabok teszik ki. Ezek nem alkotnak egységes horizontot, tehát nem in situ padló, hanem számos kisebb nagyobb darab padló töredék. Az erös bioturbáció következtében nagymértékben bolygatott az anyag. Mivel a padló töredékek lekerekített formát mutatnak, feltételezhető, hogy áthalmozott anyagról van szó. Amennyiben a padló in situ töredezéséről van szó, szögletes formák, egyenes élek jellemzők (MATTHEws et. al 1994; COURTY et. al 1994). Ebben a rétegben - bár igen apró méretü - de értékelhető mennyiségü faszén van jelen. Ezek, illetve a megjelenő hamu, csont és két kis méretü, de már szabad szemmel is jól felismerhető kerámia töredék, a mindennapi háztartási tevékenységek indikátorai (6. ábra). 

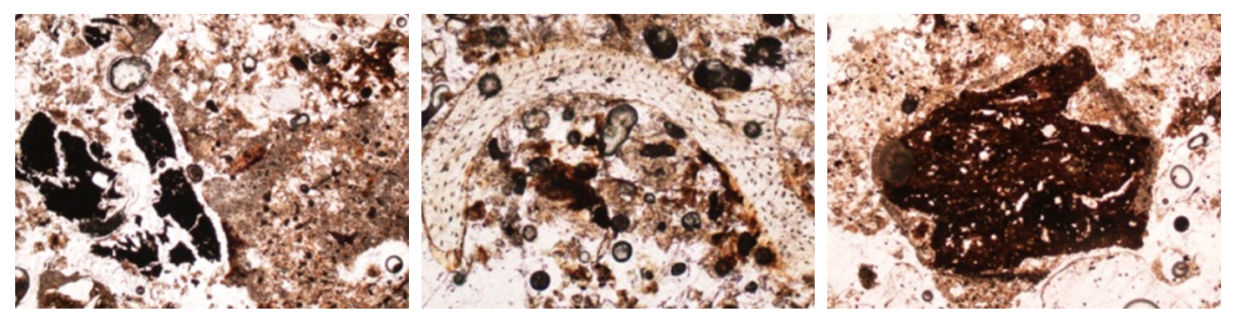

6. ábra

Faszén- (1N, 4X-es nagyítás), csont- (1N, 10X-es nagyítás), és kerámia töredék (1N, 2X-es nagyítás) mikroszkópi képe a T7-es mintában.

Bár nem beszélhetünk in situ padlóról és a rajta végzett tevékenység következtében felhalmozódott anyagokat mutató rétegröl, minden bizonnyal a mikro-töredékek a padló egykori életéhez kapcsolhatók, és éppen apró méretüknek köszönhetően kerülhettek ide a padló anyagával együtt. A rétegben található nagyobb kerámia töredék körül látható anyag egyértelmüen jelzi, hogy a töredék máshonnan egy másik közegből került a jelenleg öt befogadó anyagba (6. ábra). Ez is arra utal, hogy a réteg másodlagosan lerakásra került anyag, nem pedig in situ felhalmozódás.

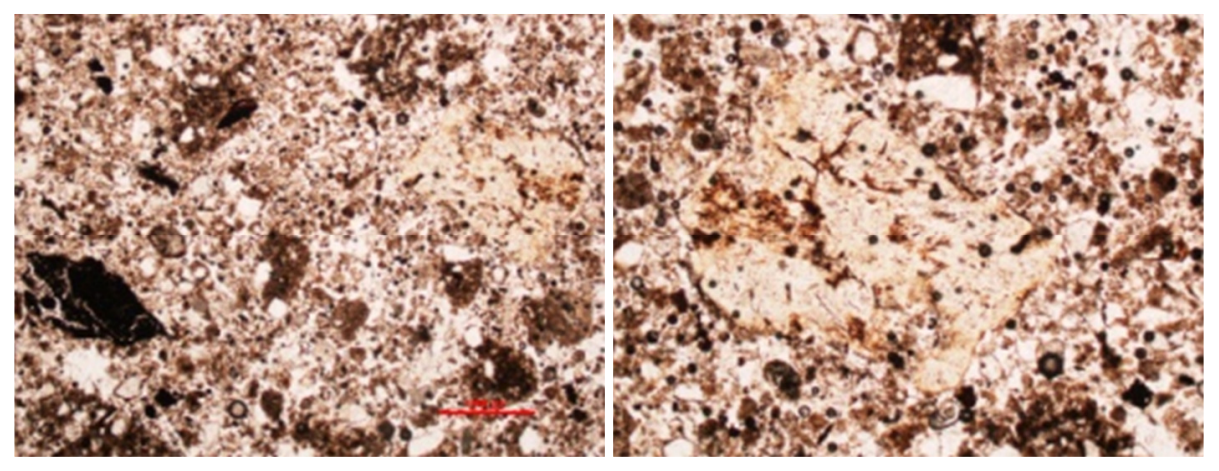

7. ábra

Faszén- (1N, 2X-es nagyítás) és csont töredék (1N, 4X-es nagyítás) mikroszkópi képe a T7es mintában

A " $b$ " rétegben még mindig számos padló töredék látható. Ez a réteg azonban egy sokkal tömörebb anyagot mutat, ami szorosan körülveszi a padló töredékeket. A megjelenő faszén és csont töredékek itt kisebb számban vannak jelen és igen apró méretủek (7. ábra). 


\section{3. táblázat}

A T7 kódjelzésű talaj mikromorfológiai mintákból készített vékonycsiszolatok vizsgálatának eredményei, valamint a mikro-rétegeket leíró megfigyelések összefoglalása.

\begin{tabular}{|c|c|c|c|}
\hline \multicolumn{4}{|c|}{$\mathrm{T} 7$} \\
\hline \multirow{3}{*}{ (1) Vizsgálati szempontok } & (2) Rétegbontás & $\mathrm{a}$ & $\mathrm{b}$ \\
\hline & (3) Réteg vastagsága & $4,8-5,7 \mathrm{~cm}$ & $3,4-5,3 \mathrm{~cm}$ \\
\hline & (4) Réteg alsó határa & (u) elmosódott & - \\
\hline \multirow{3}{*}{ (a) Struktúra } & $\begin{array}{l}\text { (f) Durva / finom összetevők aránya } \\
(500 \mu \mathrm{m})\end{array}$ & $5-10 / 95-90$ & $5 / 95$ \\
\hline & (g) Porozitás & $30-50 \%$ & $30-50 \%$ \\
\hline & (h) Bioturbáció & (v) erős & erös \\
\hline \multirow{6}{*}{ (b) Ásványi összetevők } & (i) Kvarc & $30-50 \%$ & $30-50 \%$ \\
\hline & (j) Polikristályos kvarc & $2-5 \%$ & $2-5 \%$ \\
\hline & (k) Muszkovit & $<2 \%$ & $<2 \%$ \\
\hline & (1) Glaukonit & (w) $n e ́$ & $<2 \%$ \\
\hline & (m) Biotit & $<2 \%$ & (w) né \\
\hline & (n) Klorit & $<2 \%$ & $<2 \%$ \\
\hline $\begin{array}{l}\text { (c) Biológiai eredetü } \\
\text { szervetlen maradványok }\end{array}$ & (o) Mészváz (csiga, kagyló, fosszília) & $<2 \%$ & $<2 \%$ \\
\hline (d) Szerves összetevők & (p) Faszén & $2-5 \%$ & $2-5 \%$ \\
\hline \multirow{4}{*}{ (e) Antropogén összetevők } & (q) Csont & $2-5 \%$ & $<2 \%$ \\
\hline & (r) Hamu & $10-20 \%$ & $<2 \%$ \\
\hline & (s) Kerámia töredék & $2-5 \%$ & (w) $n e ́$ \\
\hline & (t) Padló töredék & $30-40 \%$ & $10-20 \%$ \\
\hline
\end{tabular}

né: nem észlelt

A T6-os minta három rétegből áll (4. ábra; 4. táblázat). Az "a" és "b" jelü rétegeket főként ásványi összetevők alkotják (talaj jellegü réteg - homokos vályog). $\mathrm{A}$ " $b$ " rétegben lévő két miniatür csont darabka az egyetlen antropogén összetevő. A minta alsó részén (" $c$ ") néhány kisebb meszes, feltételezhetően padlótöredék figyelhető meg. Ezek réteget nem alkotnak, a járás által kialakult repedés hálózatot csak 1-2 esetben mutatják. 


\section{4. táblázat}

A T6 kódjelzésủ talaj mikromorfológiai mintákból készített vékonycsiszolatok vizsgálatának eredményei, valamint a mikro-rétegeket leíró megfigyelések összefoglalása.

\begin{tabular}{|c|c|c|c|c|}
\hline \multicolumn{5}{|c|}{ T6 } \\
\hline \multirow{3}{*}{ (1) Vizsgálati szempontok } & (2) Rétegbontás & $\mathrm{a}$ & $\mathrm{b}$ & $\mathrm{c}$ \\
\hline & (3) Réteg vastagsága & $\begin{array}{c}1,1-1,5 \\
\mathrm{~cm}\end{array}$ & $\begin{array}{c}5,0-5,6 \\
\mathrm{~cm}\end{array}$ & $\begin{array}{c}1,8-2,2 \\
\mathrm{~cm}\end{array}$ \\
\hline & (4) Réteg alsó határa & $\begin{array}{r}(\mathrm{p}) \\
\text { elmosódott }\end{array}$ & elmosódott & - \\
\hline \multirow{3}{*}{ (a) Struktúra } & $\begin{array}{l}\text { (f) Durva / finom összetevők } \\
\text { aránya }(500 \mu \mathrm{m})\end{array}$ & $5-10 / 95-90$ & $5 / 95$ & $5 / 95$ \\
\hline & (g) Porozitás & $5-10 \%$ & $5-10 \%$ & $\begin{array}{r}10- \\
20 \%\end{array}$ \\
\hline & (h) Bioturbáció & (q) enyhe & enyhe & enyhe \\
\hline \multirow{4}{*}{ (b) Ásványi összetevők } & (i) Kvarc & $50-60 \%$ & $40-50 \%$ & $\begin{array}{r}30- \\
50 \%\end{array}$ \\
\hline & (j) Polikristályos kvarc & $2-5 \%$ & $2-5 \%$ & $2-5 \%$ \\
\hline & (k) Muszkovit & $<2 \%$ & $<2 \%$ & $<2 \%$ \\
\hline & (1) Klorit & $<2 \%$ & $<2 \%$ & $<2 \%$ \\
\hline $\begin{array}{l}\text { (c) Biológiai eredetű } \\
\text { szervetlen maradványok }\end{array}$ & $\begin{array}{l}\text { (m) Mészváz (csiga, kagyló, } \\
\text { fosszília) }\end{array}$ & (r) né & $<2 \%$ & $<2 \%$ \\
\hline (e) Antropogén összetevők & (o) Csont & $n e ́$ & $<2 \%$ & $n e ́$ \\
\hline
\end{tabular}

né: nem észlelt

A T5-ös minta két részre osztható (4. ábra; 5. táblázat). Mindkét réteg többnyire ásványi anyagokból áll (talaj jellegü). Köztük a határ nem túl éles. Az antropogén eredetủ komponensek száma kevés és nem mutat változatosságot (csont és faszén van jelen) egyik rétegben sem; kifejezett tevékenységhez nem köthetők (8. ábra).

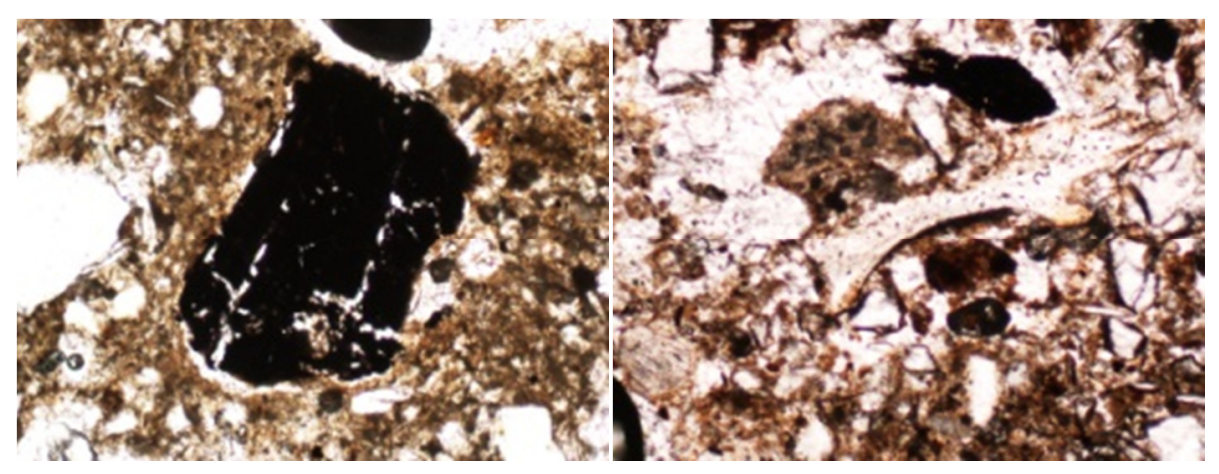

8. ábra

Faszén- (1N, 10X-es nagyítás) és csont töredék (1N, 10X-es nagyítás) mikroszkópi képe a T5-ös mintában. 


\section{5. táblázat}

A T5 kódjelzésủ talaj mikromorfológiai mintákból készített vékonycsiszolatok vizsgálatának eredményei, valamint a mikro-rétegeket leíró megfigyelések összefoglalása.

\begin{tabular}{|c|c|c|c|}
\hline \multicolumn{4}{|c|}{ T5 } \\
\hline \multirow{3}{*}{ (1) Vizsgálati szempontok } & (2) Rétegbontás & $\mathrm{a}$ & $\mathrm{b}$ \\
\hline & (3) Réteg vastagsága & $4-5 \mathrm{~cm}$ & $4,5-6,1 \mathrm{~cm}$ \\
\hline & (4) Réteg alsó határa & (q) elmosódott & - \\
\hline \multirow{3}{*}{ (a) Struktúra } & $\begin{array}{l}\text { (f) Durva / finom összetevők aránya } \\
(500 \mu \mathrm{m})\end{array}$ & $10 / 90$ & $15 / 85$ \\
\hline & (g) Porozitás & $20-30 \% \%$ & $10-20 \%$ \\
\hline & (h) Bioturbáció & (r) enyhe & enyhe \\
\hline \multirow{5}{*}{ (b) Ásványi összetevők } & (i) Kvarc & $30-40 \%$ & $40-50 \%$ \\
\hline & (j) Polikristályos kvarc & $2-5 \%$ & $2-5 \%$ \\
\hline & (k) Muszkovit & $<2 \%$ & $<2 \%$ \\
\hline & (1) Glaukonit & $<2 \%$ & (s) né \\
\hline & (m) Klorit & $<2 \%$ & $<2 \%$ \\
\hline $\begin{array}{l}\text { (c) Biológiai eredetü } \\
\text { szervetlen maradványok }\end{array}$ & (n) Mészváz (csiga, kagyló, fosszília) & $<2 \%$ & $<2 \%$ \\
\hline (d) Szerves összetevők & (o) Faszén & $<2 \%$ & $<2 \%$ \\
\hline (e) Antropogén összetevők & (p) Csont & $<2 \%$ & $<2 \%$ \\
\hline
\end{tabular}

Az " $a$ " rétegben számos feltételezhetően fal/padló töredék látható. Ezek mérete azonban kicsi és többnyire nem hordozzák a biztos határozáshoz szükséges bélyegeket, így a táblázatban nem szerepelnek. Az biztos, hogy ezek tömör homokos vályog aggregátumok, amik az eddigi megfigyelések szerint alkothatják mind a falak, mind pedig bizonyos padlók/járófelszínek anyagát. A két réteg azon túl, hogy az alsóban a feltételezhető fal/padló töredékek csak egy-két esetben figyelhetők meg, míg az " $a$ " réteg megközelítőleg $20 \%$-át teszik ki, anyagában is különbözik. Az alsó nagyobb mennyiségben tartalmaz kvarcot, vagyis homokosabb.

A T4-es minta a terepi megfigyelések szerint egy feltételezett padlót tartalmaz. A kivett földminta sajnos nem volt kellőképpen stabil, így a középső része roncsolódott még a konszolidálás elött, illetve a minta felső részén is van hiányosság az anyagban.

A minta három részre osztható (4. ábra; 6. táblázat). Az "a" réteg föként ásványi anyagokból álló talajos réteg. Benne egy szabad szemmel is jól látható padló töredék van (9. ábra), amelynek más az anyaga, mint az alatta lévő „,b” rétegben található padló daraboké. Azok inkább meszesek.

Ebben a rétegben szintén emberi tevékenységhez köthető mikrofragmentumként néhány apró égetetlen patics töredék regisztrálható. A " $b$ " réteg 60-70\%-át padló töredékek alkotják. Ezek nem alkotnak összefüggő réteget, nem in situ padló maradvány. Ezt támasztja alá a töredékek lekerekített formája és random orientációja is. Abban az esetben ugyanis, ha a töredezettség in situ alakul ki (pl. mint a repedéshálózat a terhelés következtében), akkor szögletes formákkal, és élekkel találkozunk. Az egész réteg nagyfokú bolygatottságot mutat (erős 
bioturbáció). Az apró faszén és kerámia töredék a mindennapi tevékenységhez köthető mikro fragmentumok.

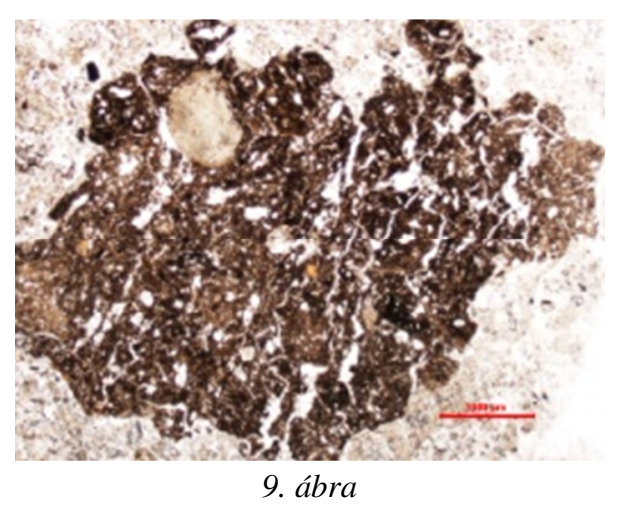

Padlótöredék mikroszkópi képe (1N, 2X-es nagyítás) a T4-es minta "a" rétegében.

A minta alsó ("c") részében lévő anyag főként ásványokból áll (talaj jellegü), a benne levő kevés és igen apró faszén és kerámia töredék mindennapi háztartási tevékenységre utal. Az apró padló töredékek pedig a felette lévő rétegből keveredtek ide.

\section{6. táblázat}

A T4 kódjelzésủ talaj mikromorfológiai mintákból készített vékonycsiszolatok vizsgálatának eredményei, valamint a mikro-rétegeket leíró megfigyelések összefoglalása.

\begin{tabular}{|c|c|c|c|c|}
\hline \multicolumn{5}{|c|}{$\mathrm{T} 4$} \\
\hline \multirow{3}{*}{ (1) Vizsgálati szempontok } & (2) Rétegbontás & $\mathrm{a}$ & $\mathrm{b}$ & $\mathrm{c}$ \\
\hline & (3) Réteg vastagsága & $\begin{array}{c}0,7-1,2 \\
\mathrm{~cm}\end{array}$ & $\begin{array}{c}3,5-3,8 \\
\mathrm{~cm}\end{array}$ & $\begin{array}{l}5,0-5,5 \\
\mathrm{~cm}\end{array}$ \\
\hline & (4) Réteg alsó határa & (r) éles & $\begin{array}{r}(\mathrm{s}) \\
\text { elmosódott }\end{array}$ & - \\
\hline \multirow{3}{*}{ (a) Struktúra } & $\begin{array}{l}\text { (f) Durva / finom összetevők } \\
\text { aránya }(500 \mu \mathrm{m})\end{array}$ & $5 / 95$ & $5 / 95$ & $5 / 95$ \\
\hline & (g) Porozitás & $10-20 \%$ & $10-20 \%$ & $10-20 \%$ \\
\hline & (h) Bioturbáció & (t) enyhe & enyhe & enyhe \\
\hline \multirow{4}{*}{ (b) Ásványi összetevők } & (i) Kvarc & $20-30 \%$ & $30-40 \%$ & $30-50 \%$ \\
\hline & (j) Polikristályos kvarc & $2-5 \%$ & $<2 \%$ & $2-5 \%$ \\
\hline & (k) Muszkovit & $<2 \%$ & $<2 \%$ & $<2 \%$ \\
\hline & (1) Klorit & $<2 \%$ & $<2 \%$ & $<2 \%$ \\
\hline $\begin{array}{l}\text { (c) Biológiai eredetủ } \\
\text { szervetlen maradványok }\end{array}$ & $\begin{array}{l}\text { (m) Mészváz (csiga, kagyló, } \\
\text { fosszília) }\end{array}$ & $<2 \%$ & $<2 \%$ & $<2 \%$ \\
\hline (d) Szerves összetevők & (n) Faszén & $n e ́$ & $<2 \%$ & $<2 \%$ \\
\hline \multirow{3}{*}{ (e) Antropogén összetevők } & (o) Kerámia töredék & $5-10 \%$ & $<2 \%$ & $<2 \%$ \\
\hline & (p) Paticstöredék & $2-5 \%$ & (u) né & $n e ́$ \\
\hline & (q) Padló töredék & $<2 \%$ & $60-70 \%$ & $<2 \%$ \\
\hline
\end{tabular}

né: nem észlelt 
A T3-as minta aljában egy égett patics darab van. Bár a terepi megfigyelés szerint itt egy feltételezett padló és a rajta lévő égett omladék látható ezt a vékonycsiszolat nem erősíti meg. A patics bár égett, in situ égetésnek nincs nyoma. Alatta (lásd T4-es minta) a feltételezett padlón sincs nyoma égésnek, az egy talajos betöltés, és a feltöredezett padló töredékeken sincs nyoma égésnek.

\section{7. táblázat}

A T3 kódjelzésű talaj mikromorfológiai mintákból készített vékonycsiszolatok vizsgálatának eredményei, valamint a mikro-rétegeket leíró megfigyelések összefoglalása.

\begin{tabular}{|c|c|c|c|}
\hline \multicolumn{4}{|c|}{ T3 } \\
\hline \multirow{3}{*}{ (1) Vizsgálati szempontok } & (2) Rétegbontás & $\mathrm{a}$ & $\mathrm{b}$ \\
\hline & (3) Réteg vastagsága & $6,5-7 \mathrm{~cm}$ & $1,2 \mathrm{~cm}$ \\
\hline & (4) Réteg alsó határa & (u) éles & - \\
\hline \multirow{3}{*}{ (a) Struktúra } & $\begin{array}{l}\text { (f) Durva / finom összetevők aránya } \\
(500 \mu \mathrm{m})\end{array}$ & $5 / 95$ & $5 / 95$ \\
\hline & (g) Porozitás & $20 \%$ & $30-50 \%$ \\
\hline & (h) Bioturbáció & (v) közepes & (w) enyhe \\
\hline \multirow{6}{*}{ (b) Ásványi összetevők } & (i) Kvarc & $20-30 \%$ & $20-30 \%$ \\
\hline & (j) Polikristályos kvarc & $2-5 \%$ & $<2 \%$ \\
\hline & (k) Muszkovit & $<2 \%$ & $2-5 \%$ \\
\hline & (1) Glaukonit & $<2 \%$ & (x) né \\
\hline & (m) Biotit & $<2 \%$ & $<2 \%$ \\
\hline & (n) Klorit & $<2 \%$ & $n e ́$ \\
\hline $\begin{array}{l}\text { (c) Biológiai eredetü } \\
\text { szervetlen maradványok }\end{array}$ & (o) Mészváz (csiga, kagyló, fosszília) & $<2 \%$ & $<2 \%$ \\
\hline (d) Szerves összetevők & (p) Faszén & $<2 \%$ & $<2 \%$ \\
\hline \multirow{4}{*}{ (e) Antropogén összetevők } & (q) Csont & $<2 \%$ & né \\
\hline & (r) Kerámia töredék & $<2 \%$ & né \\
\hline & (s) Patics & $2-5 \%$ & né \\
\hline & (t) Padló töredék & $2-5 \%$ & $n e ́$ \\
\hline
\end{tabular}

A T3 minta a terepi megfigyelések szerint a padlón lévő omladékot mintázza. A minta két részre osztható (7. táblázat). A minta alsó részén ("b") egy égett patics darab található, mely szerves anyaggal gazdagon volt soványítva (10. ábra). In situ égésnek nincs nyoma a patics környezetében. 


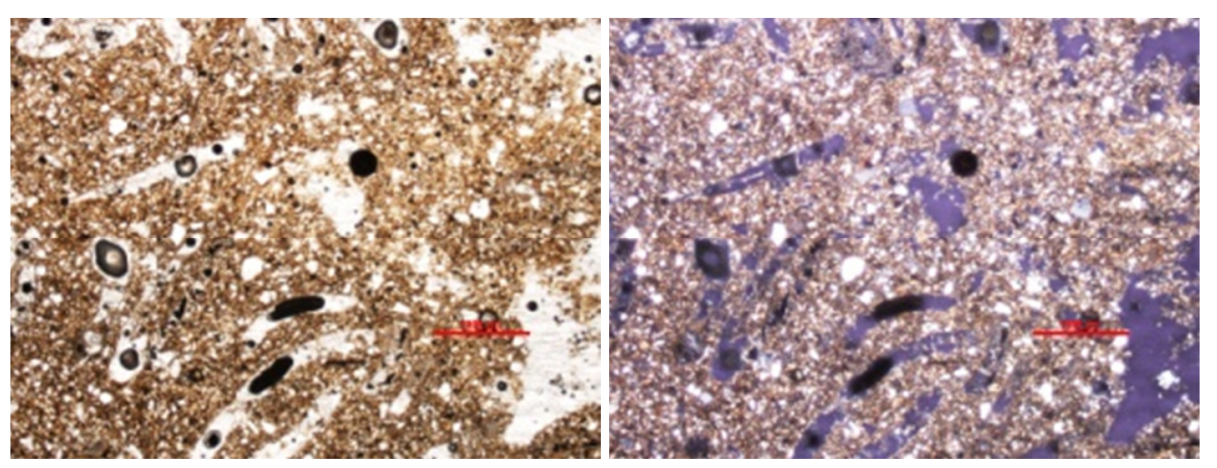

10. ábra

Szerves anyaggal soványított patics darab mikroszkópi képe a T3-as minta "b" rétegében (balra: 1N, 2X-es nagyítás; jobbra: +N, 2X-es nagyítás).

$\mathrm{Az}$ " $a$ " réteg felső $1 \mathrm{~cm}$-ében még látható néhány apró meszes padló töredék a fölötte lévő padlóból ide keveredve. Ez a betöltési réteg is főként ásványokból áll (talajos jellegü), de az apró csont, faszén, kerámia töredékek szintén jelzik, hogy korabeli háztartások tevékenységeinek nyomait örzi. A rétegen belül semmilyen orientáció, mikro-lamináció nem figyelhető meg, így ha a feltöltés szándékos is volt, akkor is egy ütemben következett be. Az " $a$ " réteg alsó harmadában apró (néhány mm nagyságú) patics töredékek láthatók. Az egész „a” rétegben igen apró az antropogén inklúziók mérete. Ez nem egy in situ omladék képét vázolja, hanem egy „átdolgozott” majd lerakott anyagét. Az apró mészvázak jelen vannak mind a paticsban mind pedig a feltöltési rétegben.

A T2 jelü mintában 3 réteg különíthetö el (4. ábra; 8. táblázat), melyböl a " $b$ " mikro-réteg egy feltételezhető padlót mutat (tipikus repedés hálózattal). Finom szerkezetủ, meszes alapanyagú padló, melyben számos mészváz töredék látható (11. ábra). 10-20\% kvarc, némi polikristályos kvarc, kevés csillám és klorit volt látható a mintában. Anyagában nem található antropogén inklúzió.

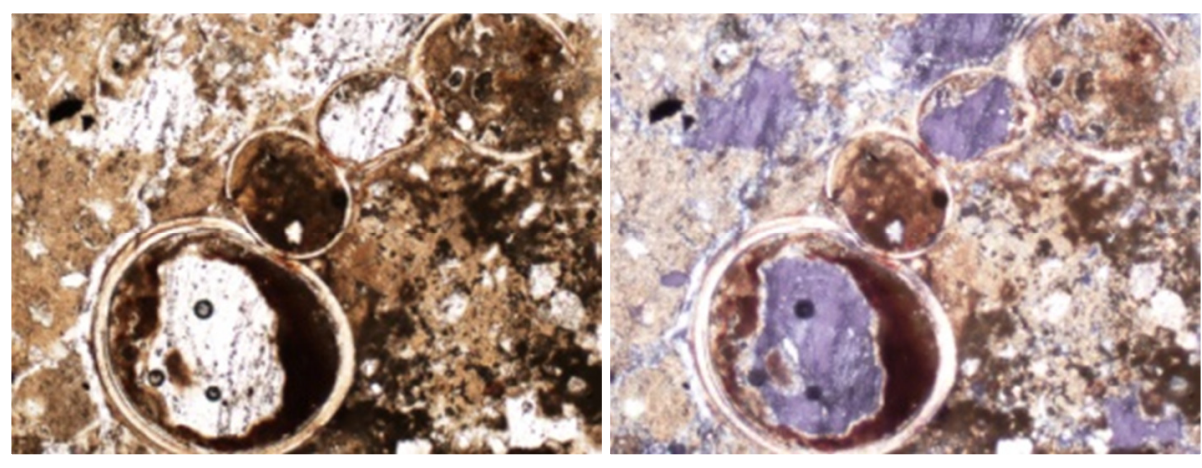

$$
\text { 11. ábra }
$$

Meszes alapanyagban lévő mészváz mikroszkópi képe a T2-es minta "b" rétegében (balra: $1 \mathrm{~N}, 10 \mathrm{X}$-es nagyítás; jobbra: +N, 10X-es nagyítás). 


\section{8. táblázat}

A T2 kódjelzésű talaj mikromorfológiai mintákból készített vékonycsiszolatok vizsgálatának eredményei, valamint a mikro-rétegeket leíró megfigyelések összefoglalása.

\begin{tabular}{|c|c|c|c|c|}
\hline \multicolumn{5}{|c|}{$\mathrm{T} 2$} \\
\hline \multirow{3}{*}{ (1) Vizsgálati szempontok } & (2) Rétegbontás & $\mathrm{a}$ & $\mathrm{b}$ & $\mathrm{c}$ \\
\hline & (3) Réteg vastagsága & $\begin{array}{c}5,9-7,0 \\
\mathrm{~cm}\end{array}$ & $\begin{array}{c}1,2-3,4 \\
\mathrm{~cm}\end{array}$ & $\begin{array}{c}0,5-2 \\
\mathrm{~cm}\end{array}$ \\
\hline & (4) Réteg alsó határa & $\begin{array}{r}(\mathrm{q}) \\
\text { elmosódott }\end{array}$ & (r) éles & - \\
\hline \multirow{3}{*}{ (a) Struktúra } & $\begin{array}{l}\text { (f) Durva / finom összetevők } \\
\text { aránya }(500 \mu \mathrm{m})\end{array}$ & $5 / 95$ & $<5 />95$ & $5 / 95$ \\
\hline & (g) Porozitás & $10-20 \%$ & $10 \%$ & $30-50 \%$ \\
\hline & (h) Bioturbáció & (s) erős & (t) enyhe & erős \\
\hline \multirow{4}{*}{ (b) Ásványi összetevők } & (i) Kvarc & $30-50 \%$ & $10-20 \%$ & $20-30 \%$ \\
\hline & (j) Polikristályos kvarc & $2-5 \%$ & $<2 \%$ & $2-5 \%$ \\
\hline & (k) Muszkovit & $<2 \%$ & $2-5 \%$ & $<2 \%$ \\
\hline & (1) Klorit & $<2 \%$ & $<2 \%$ & $<2 \%$ \\
\hline $\begin{array}{l}\text { (c) Biológiai eredetü } \\
\text { szervetlen maradványok }\end{array}$ & $\begin{array}{l}\text { (m) Mészváz (csiga, kagyló, } \\
\text { fosszília) }\end{array}$ & $2-5 \%$ & $2-5 \%$ & (u) $n e ́$ \\
\hline (d) Szerves összetevők & (n) Faszén & $<2 \%$ & né & né \\
\hline \multirow{2}{*}{ (e) Antropogén összetevők } & (o) Csont & $<2 \%$ & $n e ́$ & né \\
\hline & (p) Padló töredék & $5 \%$ & $n e ́$ & $50 \%$ \\
\hline
\end{tabular}

né: nem észlelt

A padló alatti rész ("c") nagyfokú bolygatottságot mutat a talajlakók tevékenységének következtében. Ebben a részben a fölötte lévő padlóról leszakadt apró töredékek teszik ki a minta nagy részét. Emberi tevékenységre utaló, tevékenységhez köthetö nyomot nem tartalmaz a réteg. Mivel a tömör, kemény anyagot nem tudták az apró talajlakók megkezdeni ezért alatta „közlekedtek” és ennek következtében ilyen erős a bolygatás. A leszakadt padló töredékek is erre utalnak.

A padlón lévő " $a$ " réteg sajnos nem köthető a padlón eredetileg zajlott tevékenységhez. Főként ásványokból álló (30-50\% kvarc, 2-5\% polikristályos kvarc, kevés csillám, és klorit), emberi tevékenység nyomait alig hordozó réteg. Az apró faszén és csont darabka mindennapi háztartási környezetre utal, akár csak az apró padló töredék. Az itt látható padló töredék nem meszes, mint az alatta lévő, hanem egy másik padló darabja, ami a faszénnel, csonttal együtt az egykori padló felhagyását követő pusztulás és feltöltődés során kerülhetett ide. Ebben a rétegben is számos mészváz található. 


\section{Összefoglalás}

A Kiskunsági homokhát, a Pesti hordalékkúp-síkság, illetve a Pilis-Alpári homokhát találkozásánál az ócsai Turjánvidék szomszédságában található KakucsTurján mögött lelőhely a Kárpát-medence középső bronzkorában (ca. 2000/1900 1500/1450 cal BC) a Vatya-kultúra népességének egyik jellegzetes települése volt.

A területen több talajtani módszer együttes alkalmazásával lehetőség nyílt arra, hogy feltérképezzük a bronzkori település talajtani, sekélyföldtani viszonyait, illetve a régészeti lelőhely fejlődéstörténetének, tafonómiájának egyes részleteit rekonstruáljuk.

A talajtani térképező fúrások eszközének segítségével a fedő talajképződmény alatt meghatároztuk az antropogén hatásra fejlödött és módosult talajok, valamint üledékek vertikális és horizontális kiterjedését. Ennek keretében nem csak a hármas tagolású lelőhely kerítőárkainak betöltését, hanem az épületobjektumok által megjelenített megtelepedési és pusztulási rétegeket is vizsgáltuk. A pusztulási rétegként meghatározott $\mathrm{K}_{1}$ réteg magas patics- és faszéntartalmával ellentétben az alatt elhelyezkedő - minden valószínüség szerint az eredeti megtelepedési szintet megjelenítö - $\mathrm{K}_{2}$ réteg kevesebb antropogén szemcsét tartalmazott.

Kakucs-Turján mögött bronzkori lelőhelyen végzett régészeti talaj mikromorfológiai megfigyelések arra utalnak, hogy a $\mathrm{K}_{1}$ rétegben régészeti módszerekkel meghatározott két feltételezett padló szint közül egyik sem in situ helyzetü. Bár mindkét esetben megfigyelhetők padlótöredék-darabok, ezek nagy valószínüséggel áthalmozott formában vannak jelen. Ezt támasztja alá a T4-es vékonycsiszolati mintában az égetetlen padló töredékek jelenléte, amelyek tetején égetetlen talajos jellegü betöltés és égett patics található (T3). A patics körül nincs nyoma égésnek, így az is áthalmozott anyag. A korábban padlóként meghatározott rétegtani egységek (T6 'c' és T7 ' $a$ ') ugyancsak nem in situ, hanem áthalmozott anyagként definiálhatóak. A megfigyelések arra utalnak, hogy legalább kétféle padló típussal számolhatunk a lelőhelyen. Az egyik egy igen finom szerkezetü, kifejezetten meszes, a másik pedig homokos vályog alapanyagú. Ebből az anyaghasználat, építéstechnika, ezzel együtt pedig esetlegesen a helyhasználat különbözőségére következtethetünk.

Az antropogén eredetü összetevők aránya alacsony. Talán ez is annak a jele, hogy nem egy in situ házzal/épülettel, hanem annak áthalmozott maradványaival van dolgunk. Az antropogén eredetü mikro-maradványok a mindennapi élethez kapcsolhatók (pl. hamu, faszén - égetés; csont - élelem, ételkészítés; kerámia tárolás, fazekasság). Az elemzett vékonycsiszolatok az anyagok folyamatos áthalmozását mutatják, ami intenzív emberi jelenlétre utal.

A vékonycsiszolatokban megfigyelt, a telepen zajló anyagmozgatás, áthalmozás mértékével kapcsolatban általánosítani nem lehet. A mintázott profil azonban jól mutatja a szándékos anyagmozgatást, áthalmozást, mely a mintázás helyén sem egyszeri esemény. A padlók esetében régészetileg is bizonytalan interpretációt (,feltételezett padló”) szándékoztunk megerősíteni vagy elvetni. A terepi megfigyelések szerint valószínüsíthető volt a mintázott helyen padlók megléte, melyek nem őrződtek meg minden kétséget kizáróan. A vékonycsiszolatok 
megfigyelései igazolták a padlók (pontosabban padló alapanyagok) meglétét, hisz valóban padló anyag került lerakásra, de ezek vélhetően nem elsődleges, azaz kialakításuk pozíciójában voltak jelen. „Bolygatatlan” padló töredéket csupán a T2es mintában találtunk. Bár mintázáskor itt nem rögzítettük padló jelenlétét, mind az ásatási dokumentáció mind pedig a mikroszkópos megfigyelés azt mutatja, hogy in situ padlót találtunk.

A homokos/homokos vályog szerkezetnek köszönhetően a szerves (növényi) anyagok megörződése igen rossz. Gyakorlatilag nincsenek jelen a mintákban, így ezekkel kapcsoltban nem állt módunkban megfigyeléseket tenni.

$\mathrm{Az}$ intenzív emberi jelenlét az egész lelőhelyen megfigyelhetö, melyet a fúrások során tapasztalt változó vastagságú kultúrréteg is mutat. A telep egyes részein anyagok halmozódtak fel, kerültek lerakásra, míg máshol ilyen jellegü tevékenység nem figyelhető meg, sekélyebb üledékréteget hátrahagyva.

Mind a talajfúrások, mind pedig a vékonycsiszolatok elemzése alapján a lelőhelyképződés a következőképen vázolható:

1. Eredeti természeti környezet

2. Emberi megtelepedés

3. Az eredeti/eltemetett talaj felszínének modifikációja, mely nem drasztikus, hanem folyamatos.

4. Folyamatos emberi behatás (házak építése, mindennapi tevékenység következtében kialakuló anyagok felhalmozódása (kerámia, patics, csont, hamu stb.), anyagok áthalmozása).

5. Telep el/felhagyása, a telep pusztulása, eltemetődése

6. Recens talajfejlödés

Kulcsszavak: régészeti talaj-mikromorfológia, lelőhelyképződés, geoarcheológia, vékonycsiszolat

\section{Köszönetnyilvánítás-Együttmüködés}

A kutatásokat a National Science Center of Poland (grant no. 2012/05/B/HS3/03714) támogatta. A lelőhely geofizikai felmérését Márkus Gábor (Archeodata 1998 Bt.) végezte. A talajtani fúrások és elemzések az NKA (3234/261) támogatásával készülttek. A vékonycsiszolatokat Budai Ferenc készítette. 


\section{Irodalom}

BARCZI, A., 2016: Kunhalmok eltemetett talajainak vizsgálata. Szent István Egyetemi Kiadó Nonprofit Kft., Gödöllő, p. 179 ISBN 978-963-269-588-4

COURTy, M. A., GOLDBERG, P. AND MACPHAIL, R. I. 1994. 'Ancient people: lifestyles and cultural patterns'. In: WILDING, L. \& OLESHKO, K. (eds), Micromorphological indicators of anthropogenic affects on soils. Transaction of the 15th World Congress of Soil Science. Volume 6a, Acapulco: 250-269.

Dezsö, J., Bertók, G., Bognár, A., Kaposvári, F., Darányi, V., Pethe, M., Csabai, Z., PÁll-Gergely, B., SIPOS, GY., 2009: Pedológiai-szedimentológiai vizsgálatok lösszel borított területeken, Szemely-Hegyes későneolitikus körárokrendszer példáján. Archeometriai Mühely. VI/3. 57-72.

DöVÉNYI, Z. (szerk.), 2010. Magyarország kistájainak katasztere. Budapest. MTA Földrajztudományi Kutatóintézet. 876. p.

KovÁcs, G., 2009. Geoarchaeological Investigation of Százhalombatta-Földvár Bronze Age tell settlement in Hungary, PhD disszertáció, Cambridge, Anglia, 339.

KovÁCS, G., 2011. Régészeti talaj-mikromorfológia. Antropogén rétegek talajmikromorfológiai vizsgálata. Matrica Füzetek III., Százhalombatta. 56.

Kulcsár, G., Jaeger, M., Kiss, V., Márkus, G., Müller, J., Petö, Á., Serlegi, G., SZEVERÉNYI, V., TAYLOR, N., 2014. The beginnings of a new research program Kakucs Archaeological Expedition - KEX1. Hungarian Archaeology. 2014 Winter. $1-7$.

MAROSI, S. \& SoMOGYI, S. (szerk.), 1990. Magyarország kistájainak katasztere. Magyar Tudományos Akadémia Földrajztudományi Kutató Intézet. Budapest.

Matthews, W., Postgate J. N., Payne, S., Charles M. P., Dobney, K. 1994 The imprint of living in an early Mesopotamian city: questions and answers. In LUFF, R. \& ROWLEYConwy, P. (eds.) Whither environmental archaeology? Oxbow Monograph 38: 171212.

MuRPHY, C.P. 1986 Thin section preparation of soils and sediments. A.B. Academic, Berkhamsted, 149.

PETŐ, Á., KENÉZ, Á. \& REMÉNYI, L., 2013. Régészeti talajtani kutatások Perkáta, Forrás-dülő bronzkori földváron. Agrokémia és Talajtan. 62(1). 61-80.

Petö, Á., Serlegi, G., Krausz, E., Jaeger, M., Kulcsár, G., 2015. Régészeti talajtani megfigyelések "Kakucs-Turján mögött" bronzkori lelőhelyen I. Agrokémia és Talajtan. 64(1). 219-237.

Petö, Á., Serlegi, G., Krausz, E., Jaeger, M., Kulcsár, G., 2016. Régészeti talajtani megfigyelések "Kakucs-Turján mögött" bronzkori lelőhelyen II.: Az árokrendszer. Agrokémia és Talajtan. 65(2). 225-242.

REMÉNYI, L., 2012. The Defensive Settlements of the Vatya Culture and the Central European Bronze Age Exchange System In: Jaeger, M., Czebreszuk, J. \& P. Fischl, K. (Eds.) Enclosed Space - Open Society. Contact and Exchange in the Context of Bronze Age Defensive Settlements in Central Europe. (Stud. z. Archäol. in Ostmitteleuropa, 9), 275-286.

Saláta, D., Krausz, E., Reményi, L., Kenéz, Á., Petö, Á., 2014. Combining historical land-use and geoarchaeological evidence to support archaeological site detection. Agrokémia és Talajtan. 63(1). 99-108. 
SÁNDOR, E., 2011. A mendei Leányvár talajvédelmi vizsgálata és annak lehetséges kulturális örökségvédelmi vonatkozásai. Szakdolgozat, Szent István Egyetem, Mezőgazdaság- és Környezettudományi Kar, Környezet- és Tájgazdálkodási Intézet, Természetvédelmi és Tájökológiai Tanszék, Gödöllő, 70.

Stoops, G., 2003. Guidelines for analysis and description of soil regolith and thin section. Soil Science Society of America Inc., Madison, Wisconsin, USA, 184.

SzeVERÉNYI, V., KulCSÁR, G., 2012 : Middle Bronze Age Settlement and Society in Central Hungary. In: Jaeger, M., Czebreszuk, J. \& P. Fischl, K. (Eds.) Enclosed Space - Open Society. Contact and Exchange in the Context of Bronze Age Defensive Settlements in Central Europe. (Stud. z. Archäol. in Ostmitteleuropa, 9), 287-351

VArga, A., 2000. Coring results at Százhalombatta -Földvár. In: Poroszlai I. - Vicze M. (eds.): SAX - Százhalombatta Archaeological Expedition Annual Report 1. Field Season 1998. Százhalombatta. 75-81.

ViCZE, M., CZAJLIK, Z. \& TíMÁR, L., 2005 Aerial and topographical research of the Benta Valley. In: Poroszlai, I. \&Vicze, M. (Eds.) SAX - Százhalombatta Archaeological Expedition Annual Report 2 - Field Season 2000-2003. Százhalombatta, 251-254.

\title{
Results of the soil micro-morphological analysis at Bronze Age archaeological site known as 'behind Kakucs-Turján'
}

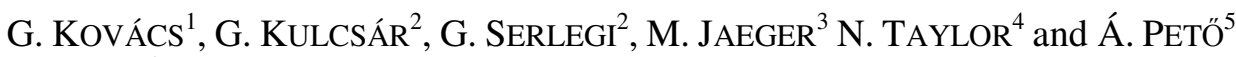 \\ ${ }^{1}$ 'Matrica' Museum and Archaeological Park, Százhalombatta \\ ${ }^{2}$ Institute of Archaeology, Research Centre for the Humanities, Hungarian \\ Academy of Sciences, Budapest \\ ${ }^{3}$ Institute of European Culture, Adam Mickiewicz University, Poznań \\ ${ }^{4}$ Christian-Albrechts-Universität zu Kiel Institut für Ur- und Frühgeschichte, Kiel \\ ${ }^{5}$ Institute of Nature Conservation and Landscape Management, Szent István \\ University, Gödöllő
}

\section{Summary}

The 'behind Kakucs-Turján' site is located at the junction of the Kiskunsági sand, the Pest alluvial plain and the Pilis-Alpári sand, in the neighbourhood of Turjánvidék in Ócsa. The site is one of the typical settlements of the Vatya Culture found in the Carpathian Basin during the Middle Bronze Age (approx. 2000 / 19001500 / 1450 cal BC).

A survey of the soil and of the shallow geology of the Bronze Age settlement became possible using a combination of various soil science methods. A partial reconstruction of the site formation processes and the specification of certain taphonomical details were also achieved.

The vertical and horizontal expansion of the buried anthropogenic sediment and the prehistoric anthrosol could be determined by shallow geological drilling. With the aid of the soil corings not only the infill of the surrounding ditches of the tripartite site, but also the phases of the settling process and the decay of the latter could be investigated. Layer K1 (identified as the layer of decay) contained large amounts of daub and charcoal, in contrast to layer K2, which is considered to be the 
layer where settling commenced and which contained lower amounts of anthropogenic components.

The thin-section soil micro-morphological observations at the 'behind KakucsTurján' Bronze Age settlement suggest that neither of the two floors previously assumed to belong to layer K1 are in situ. Although fragments of flooring could be identified in both cases, they are now considered to be the results of secondary deposition. This hypothesis is supported by the presence of unburnt floor fragments in sample T4, which were covered by soil-like infill with burnt daub (T3) on top. Since no sign of in situ burning can be detected around the burnt daub, it can only be the result of secondary deposition. The younger of the previously assumed floors (T6 ' $c$ ' and T7 ' $a$ ') is not in situ either. This layer also seems to be the result of secondary deposition. Although no in situ floor could be identified, the results show that different types of materials were used during the preparation of the floors. One of them is very fine and highly calcareous, while the other one is a sandy loam type. This could indicate the deliberate choice of a specific building material or might be related to differences in building techniques. Furthermore, it might reflect differences in the use of space. There are very few anthropogenic components in the samples, also suggesting the presence of secondarily deposited building materials rather than in situ floors/remnants of buildings. The anthropogenic micro-fragments found are all related to everyday life (i.e. ash and charcoal - fires; bone - food, food preparation; ceramics - storage, pottery). The analysed samples show the continuous reworking of the various materials, suggesting intensive human activity. Due to the sandy/sandy loam type soil of the area, very little organic (plant) matter has been preserved, and is virtually absent from the thin sections investigated.

Intensive human effect can be traced throughout the settlement, which is also proved by the results of the soil coring (varied thickness and composition of the cultural layer). Some parts of the site show sediment accumulation and intentional deposition, while other areas show no sign of such action leaving a shallow sediment layer behind. Based on the analysis of soil drillings and thin sections, the site formation can be outlined as follows:

1. Original natural environment

2. Human settling

3. Surface modification of the original/buried soil, which is not drastic but continuous.

4. Continuous human impact (construction of houses, accumulation of materials arising from everyday activities (ceramics, daub, bone, ash, etc.), re-deposition of materials).

5. Abandonment, destruction, burial of the settlement

6. Recent soil development

Key words: archaeological thin-section soil micromorphology, site formation, geoarchaeology, thin sections

Table 1. Results of the micromorphological analysis of thin-section sample T1 and description of the sub-layers. (1) Parameters. (2) Sub-layers. (3) Thickness of 
sub-layer. (4) Transition of the sub-layer. (a) Structure; (b) Mineral composition; (c) Inorganic particles of biological origin; (d) Organic particles; (e) Anthropogenic particles; (f) Ratio of coarse and fine fractions; (g) Porosity; (h) Bioturbation; (i) Quartz; (j) Polycrystalline quartz; (k) Muscovite; (l) Chlorite; (m) Mollusc shell remains; (n) Charcoal; (o) Bone; (p) Ceramic fragment; (q) diffuse; (r) significant; (s) moderate; (t) not observed.

Table 2. Results of the micromorphological analysis of thin-section sample T8 and description of the sub-layers. (1) Parameters. (2) Sub-layers. (3) Thickness of sub-layer. (4) Transition of the sublayer. (a) Structure; (b) Mineral composition; (c) Inorganic particles of biological origin; (d) Organic particles; (e) Anthropogenic particles; (f) Ratio of coarse and fine fractions; (g) Porosity; (h) Bioturbation; (i) Quartz; (j) Polycrystalline quartz; (k) Muscovite; (l) Chlorite; (m) Mollusc shell remains; (n) Charcoal; (o) Ash; (p) Ceramic fragment; (q) Floor fragment; (r) slight.

Table 3. Results of the micromorphological analysis of thin-section sample T7 and description of the sub-layers. (1) Parameters. (2) Sub-layers. (3) Thickness of sub-layer. (4) Transition of the sub-layer. (a) Structure; (b) Mineral composition; (c) Inorganic particles of biological origin; (d) Organic particles; (e) Anthropogenic particles; (f) Ratio of coarse and fine fractions; (g) Porosity; (h) Bioturbation; (i) Quartz; (j) Polycrystalline quartz; (k) Muscovite; (l) Glauconite; (m) Biotite; (n) Chlorite; (o) Mollusc shell remains; (p) Charcoal; (q) Bone; (r) Ash; (s) Ceramic fragment; (t) Floor fragment; (u) diffuse; (v) significant; (w) not observed.

Table 4. Results of the micromorphological analysis of thin-section sample T6 and description of the sub-layers. (1) Parameters; (2) Sub-layers; (3) Thickness of sub-layer; (4) Transition of the sub-layer; (a) Structure; (b) Mineral composition; (c) Inorganic particles with biological origin; (d) Organic particles; (e) Anthropogenic particles; (f) Ratio of coarse and fine fraction; (g) Porosity; (h) Bioturbation; (i) Quartz; (j) Polycrystalline quartz; (k) Muscovite; (l) Chlorite; (m) Mollusc shell remains; (o) Bone; (p) diffuse; (q) slight; (r) not observed.

Table 5. Results of the micromorphological analysis of thin-section sample T5 and description of the sub-layers. (1) Parameters. (2) Sub-layers. (3) Thickness of sub-layer. (4) Transition of the sub-layer. (a) Structure; (b) Mineral composition; (c) Inorganic particles of biological origin; (d) Organic particles; (e) Anthropogenic particles; (f) Ratio of coarse and fine fractions; (g) Porosity; (h) Bioturbation; (i) Quartz; (j) Polycrystalline quartz; (k) Muscovite; (l) Glauconite; (m) Chlorite; (n) Mollusc shell remains; (o) Charcoal; (p) Bone; (q) diffuse; (r) slight; (s) not observed.

Table 6. Results of the micromorphological analysis of thin-section sample T4 and description of the sub-layers. (1) Parameters. (2) Sub-layers. (3) Thickness of sub-layer. (4) Transition of the sub-layer. (a) Structure; (b) Mineral composition; (c) Inorganic particles of biological origin; (d) Organic particles; (e) Anthropogenic particles; (f) Ratio of coarse and fine fractions; (g) Porosity; (h) Bioturbation; (i) Quartz; (j) Polycrystalline quartz; (k) Muscovite; (l) Chlorite; (m) Mollusc shell remains; (n) Charcoal; (o) Ceramic fragment; (p) Daub fragment; (q) Floor fragment; (r) sharp; (s) diffuse; (t) slight; (u) not observed. 
Table 7. Results of the micromorphological analysis of thin-section sample T3 and description of the sub-layers. (1) Parameters. (2) Sub-layers. (3) Thickness of sub-layer. (4) Transition of the sub-layer. (a) Structure; (b) Mineral composition; (c) Inorganic particles of biological origin; (d) Organic particles; (e) Anthropogenic particles; (f) Ratio of coarse and fine fractions; (g) Porosity; (h) Bioturbation; (i) Quartz; (j) Polycrystalline quartz; (k) Muscovite; (l) Glauconite; (m) Biotite; (n) Chlorite; (o) Mollusc shell remains; (p) Charcoal; (q) Bone; (r) Ceramic fragment; (s) Daub; (t) Floor fragment; (u) sharp; (v) moderate; (w) slight; (x) not observed.

Table 8. Results of the micromorphological analysis of thin-section sample T2 and description of the sub-layers. (1) Parameters. (2) Sub-layers. (3) Thickness of sub-layer. (4) Transition of the sub-layer. (a) Structure; (b) Mineral composition; (c) Inorganic particles of biological origin; (d) Organic particles; (e) Anthropogenic particles; (f) Ratio of coarse and fine fractions; (g) Porosity; (h) Bioturbation; (i) Quartz; (j) Polycrystalline quartz; (k) Muscovite; (l) Chlorite; (m) Mollusc shell remains; (n) Charcoal; (o) Bone; (p) Floor fragment; (q) diffuse; (r) sharp; (s) significant; (t) slight; (u) not observed.

Figure 1. Geophysical prospection of the 'behind Kakucs-Turján' archaeological site, and location of the coring points, excavation trench and micromorphological samples.

Figure 2. Position of the micromorphological samples in the profile of the excavation trench at 'behind Kakucs-Turján mögött' archaeological site.

Figure 3. Micrograph of thin-section sample T1 and the sub-layers identified. Note: Magnification refers to that of the microscope's objective; the real magnification was ten times as great (a) Matrix; (b) bone fragment.

Figure 4. Micrograph of thin-section samples T2-T8 and the sub-layers identified.

Figure 5. Ash with charcoal fragments in thin-section sample T8 (1N, 20x).

Figure 6. Charcoal $(1 \mathrm{~N}, 40 \mathrm{x})$, bone $(1 \mathrm{~N}, 100 \mathrm{x})$ and ceramic $(1 \mathrm{~N}, 20 \mathrm{x})$ fragments in thin-section sample T7.

Figure 7. Charcoal $(1 \mathrm{~N}, 20 \mathrm{x})$ and bone $(1 \mathrm{~N}, 40 \mathrm{x})$ fragments in thin-section sample T7.

Figure 8. Charcoal $(1 \mathrm{~N}, 100 \mathrm{x})$ and bone $(1 \mathrm{~N}, 100 \mathrm{x})$ fragments in thin-section sample T5. $\mathrm{T} 4$.

Figure 9. Floor fragment $(1 \mathrm{~N}, 20 \mathrm{x})$ in the 'a' sub-layer of thin-section sample

Figure 10. Daub fragment tempered with organic material; microphotography from sub-layer ' $b$ ' of thin-section sample T3 (left: 1N, 20x; right: $+\mathrm{N}, 20 \mathrm{x}$ ).

Figure 11. Mollusc shell fragment in sub-layer ' $b$ ' of thin-section sample T2 (left: 1N, 100x; right: $+\mathrm{N}, 100 \mathrm{x}$ ). 